\title{
Identification of Implementation Lean, Agile, Resilient and Green (LARG) Approach in Indonesia Automotive Industry
}

\author{
Siti Aisyah ${ }^{1 *}$, Humiras Hardi Purba ${ }^{2}$, Choesnul Jaqin ${ }^{2}$, Zulfi Restu Amelia ${ }^{3}$, Hendra Adiyatna ${ }^{4}$ \\ ${ }^{1}$ Automotive Industrial Engineering Study Program, Polytechnic STMI Jakarta, Jakarta 10510, Indonesia \\ ${ }^{2}$ Industrial Engineering Department, Mercu Buana University, Jakarta 11650, Indonesia \\ ${ }^{3}$ Food Technology Department, Sahid University, Jakarta 12870, Indonesia \\ ${ }^{4}$ Industrial Engineering Department, Bina Tunggal College of Technology, Bekasi 17134, Indonesia
}

Corresponding Author Email: lalita1712aisyah@gmail.com

https://doi.org/10.18280/jesa.540214

Received: 18 October 2020

Accepted: 13 December 2020

\section{Keywords:}

automotive, IPA, index, $L A R G$

\begin{abstract}
Indonesia's economic growth, which has developed in the last few decades, has contributed to an increase in the automotive industry sector. The automotive industry continues to increase the competitiveness of the automotive industry. The Lean, Agile, Resilient, Green (LARG) approach that has been applied by several global automotive industries, is able to increase competitiveness and performance in a sustainable manner. The purpose of this study is to analyze the implementation of the LARG approach in Indonesian automotive, as one of the bases for the automotive industry in Asia. The LARG value index is conducted to determine the level of application in the automotive industry in Indonesia. The mapping of the level of importance and performance of each of the LARG sub indicators was carried out using the Importance Performance Analysis (IPA) method. The results of this study confirm that there are several LARG sub indicators that have not been implemented properly. Green has the most sub-indicators that need to be improved, namely $\mathrm{P}_{\mathrm{G} 1}$ (ISO 14000 and OHSAS Certificates), $\mathrm{P}_{\mathrm{G} 2}$ (Collaboration with suppliers and customers in protecting the environment), $\mathrm{P}_{\mathrm{G} 6}$ (Carrying out industrial waste recycling), and $\mathrm{P}_{\mathrm{G} 8}$ (Product design that can reduce consumption of energy and raw materials). The calculation of the LARG implementation index value is 4.41.
\end{abstract}

\section{INTRODUCTION}

The problem of low productivity in national industry often attracts the world's attention along with the intense competition, particularly in the automotive industry. This problem is mainly related to the human factor involved in the industry besides other factors concerning the production process. Industrial capability highly depends on human resource skills as the major factor of competitive advantage supported by the implementation of an excellent industrial system. This system does not only focus on the factor of efficiency and effectiveness, but also includes the factor of customer needs and customer wants, also supplier, by still maintaining environmental sustainability. The integrated approach is known as LARG (Lean, Agile, Resilient, and Green). LARG is an approach that is able to provide positive impact on industry to compete and survive in a tough business condition.

There is no much comprehensive research on the application of LARG in the automotive industry in Indonesia, where some research focuses on the application of lean only. The research by Purba et al. [1] examined aspects of value stream mapping (VSM) for picking order improvements. Other studies generally focus on the application of lean and kaizen [2, 3].

Study based on assessment of the implementation of Lean, Agile, Resilient, and Green (LARG) in automotive industry is strategic to apply to further obtain the value of LARG implementation. This way, such strategic steps are possible to formulate in order increase each LARG index [4-6]. The authors and the previous partner have collaborated to analyze the implementation of Lean and Six Sigma and published academic work in the form of book titled: Quality Improvement and Lean Six Sigma in 2017. Study based on assessment of LARG implementation in automotive industry could provide description indicating the level of importance of each indicator for the industry. Hence, the industry will be able to comprehend global depiction and ideal condition for each LARG index, where the factor of green industry becomes a major concern for every industry. The objective of this study was to analyze the implementation of LARG approach in automotive industry in Indonesia and to identify the indicators affecting sustainable competitiveness of automotive industry.

\section{METHODOLOGY}

\subsection{Framework}

Research framework was started from the problem of automotive industry competitiveness concerning the implementation of LARG approach, followed by identification of other problems that also affected the sustainable competitiveness of automotive industry. 


\subsection{Calculation of LARG index}

Determination of sub indicator of each LARG Approach can be obtained from many literatures, then experts (in LARG Implementation in Indonesia automotive) assess the importance or not importance of each of these sub indicators by using questionnaire. After the data is processed, $10 \mathrm{sub}$ indicators of expert that are most suitable are implemented in the Indonesia automotive industry. The results of these experts are used to create a questionnaire that will be filled in by the automotive industry on the implementation of the LARG approach in the industry. Calculation of LARG index in this study followed the hierarchical relationship of behavioral assessment of an industry adapted by Aisyah et al. [5,6]. The indicators show the behavior of each industry in the index of leanness, agility, resilient, and greenness. These indicators are combination of group of information in sub-indicators: lean behavior in industry $\left(P_{L 1}, \ldots, P_{L t}\right)$; agile behavior in industry $\left(P_{A 1}, \ldots, P_{A t}\right)$; resilient behavior in industry $\left(P_{R 1}, \ldots, P_{R t}\right)$; and green behavior in industry $\left(P_{G 1}, \ldots, P_{G t}\right)$. Each subindicator was assessed using the Likert scale 1-5 where, 1 indicates "behavior is not implemented and 5 means "behavior is completely implemented".

Each industry could calculate the importance level of each indicator based on the importance of each sub-indicator. The importance of indicator $\left(B_{x}\right)$ in each industry $(j)$ was calculated using Eq. (1) where $x$ is $L$ (lean), $A$ (agile), $R$ (resilient), and $G$ (green). Eq. (1) shows industrial behavior according to the behavioral implementation level $\left(P_{x y}\right)$ and the weight of each behavior $\left(w_{x y}\right)$.

$$
\left(B_{x}\right)_{j}=f\left[w_{x 1} \times\left(P_{x 1}\right)_{j}, \ldots, w_{x y} \times\left(P_{x y}\right)\right]
$$

with $w_{x i} \geq 0$ and $\sum w_{x i}=1$

where, $\left(B_{x}\right)_{j}$ is the behavior of automotive industry $j$ with $x(x=L, A, R, G) .\left(P_{x i}\right)_{j}$ is implementation level of behavior $i$ toward the paradigm $x$ in automotive industry $j$. Number of behavior $y$ is based on each paradigm. Each implementation level of behavior was assessed using Likert scale 1-5. $w_{x i}$ is the weight of behavior $i$ in paradigm $x$. The value of weight shows importance of each behavior for improvement of sustainable competitiveness of automotive industry in which the value between 0 "unimportant" and 1 "highly important".

The value of behavior $\left(B_{x}\right)$ is the level of behavior implementation for each automotive industry. The LARG Index was further calculated for each automotive industry $\left(L A R G_{j}\right)$ using Eq. (2).

$$
\begin{aligned}
L A R G_{j}=f\left[w_{L} \times\right. & \left(B_{L}\right)_{j}, w_{A} \times\left(B_{A}\right)_{j}, w_{R} \times\left(B_{R}\right)_{j}, w_{G} \\
& \left.\times\left(B_{G}\right)_{j}\right]
\end{aligned}
$$

with $w_{L}, w_{A}, w_{R}, w_{G} \geq 0$ and $w_{L}, w_{A}, w_{R}, w_{G}=1$.

where, $\left(B_{x}\right)_{j}$ is automotive industry $j$ with behavior based on paradigm $x(x=L, A, R, G)$ and $w_{L}, w_{A}, w_{R}, w_{G}$ is the weight of LARG paradigm.

The value of weight shows importance of each paradigm for sustainable competitiveness of automotive industry. The weight value ranged between 0 "unimportant" and 1 "highly important". The LARG index of automotive industry had a range value from 1 "no paradigm is implemented by automotive industry" and 5 "all paradigm is implemented by automotive industry.
Calculation of weight for each LARG paradigm was done using Delphi approach. Delphi is a technique formulated from communication method that is designed to extract maximum amount of unbiased information obtained from the opinion of a panel of experts [7]. Each importance of paradigm was determined based on score between 1-5, where 1 "unimportant" and 5 "highly important". Moreover, the value of weight for each LARG paradigm was calculated using Eq. (3).

$$
w_{x}=\frac{M_{x}}{\sum_{g=1}^{n} M_{g}}
$$

where, $w_{x}$ is the weight of paradigm $x, M_{x}$ is the average value of importance level of each paradigm $x$ and $\sum_{g=1}^{n} M_{g}$ is the total average value of importance of total paradigm.

\subsection{The priority of indicator required to be improved}

Determination of indicator to be improved was done through the Importance Performance Analysis (IPA). IPA is an effective method to determine priority. Analysis was conducted in two dimensions to compare the level of importance and performance of each indicator. This analysis resulted in area of priority to be maintained and improved also area that might be a 'possible overkill' area, less useful, and should be eliminated from the priority [8]. Analysis was done by comparing the result of importance of each indicator according to experts and result of implementation in the automotive industry using the quadrant of the analysis of importance and performance as shown in Figure 1.

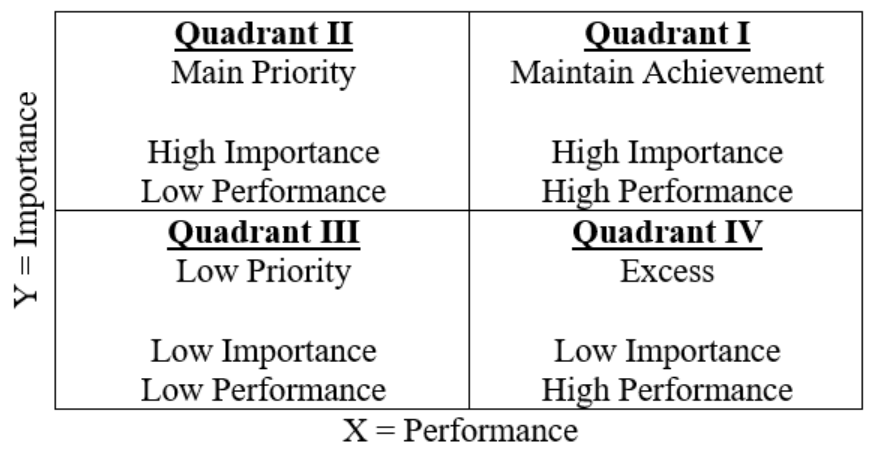

Figure 1. Distribution of quadrant of importance and performance [9]

\section{RESULTS AND DISCUSSION}

\subsection{Results of importance assessment for LARG issue according to experts}

The LARG indicator and its sub-indicator were selected by considering the effect on the condition of were 40 indicators used in the assessment of LARG issue in the industry. Each indicator consisted of $10 \mathrm{sub}$-indicators as listed in Table 1.

A total of forty LARG sub-indicators were assessed by Experts to determine the importance rank of each subindicator of the indicator analyzed. Furthermore, calculation of the average importance value of each indicator and the total of average importance value was done to compute the weight of each indicator. The LARG Index was calculated using Eq. (2). The result of calculation is shown in Table 2. 
Table 1. Indicator and sub-indicator of LARG

\begin{tabular}{|c|c|c|c|}
\hline & Sub-indicator & & Sub-indicator \\
\hline \multirow{10}{*}{ క్ } & PL1: Just in Time (JIT) [10-12] & \multirow{10}{*}{$\stackrel{\widetilde{\sigma}}{\mathbb{*}}$} & $\mathrm{P}_{\mathrm{A} 1}$ : Product design according to consumer demand [13] \\
\hline & PL2: Reduce lot size $[14,15]$ & & $\mathrm{P}_{\mathrm{A} 2}$ : Ability to get information about demand quickly [16] \\
\hline & $P_{\text {L3 }}:$ Reduce cycle time and setup time $[6,15,17]$ & & $\begin{array}{c}\mathrm{P}_{\mathrm{A} 3} \text { : Speed in improving consumer service, delivery reliability, } \\
\text { and response to market change }[16,18]\end{array}$ \\
\hline & PL4: Reduce WIP $[10,11,15]$ & & $\begin{array}{l}\mathrm{P}_{\mathrm{A} 4} \text { : Reliability of increasing response to changes in market } \\
\text { needs [19] }\end{array}$ \\
\hline & $\mathrm{P}_{\mathrm{L} 5}$ : Shorten leadtime $[11,15]$ & & $\begin{array}{l}\mathrm{P}_{\mathrm{A} 5} \text { : Ability to re-configure the production plan and process } \\
\text { quickly }[13,20]\end{array}$ \\
\hline & PL6: Build an independent quality/ control system [21] & & $\mathrm{P}_{\mathrm{A} 6}$ : Innovation ability/skill to satisfy consumer demand $[22,23]$ \\
\hline & PL7: Multi-skilled worker $[21,24]$ & & $\begin{array}{l}\mathrm{P}_{\mathrm{A} 7} \text { : Application of IT in integrating all industrial activities [22, } \\
23]\end{array}$ \\
\hline & PL8: Increase the use of resources [25] & & $\mathrm{P}_{\mathrm{A} 8:}$ The use of multi-skilled and flexible worker [26] \\
\hline & $\mathrm{P}_{\mathrm{L} 9}$ : Design for manufacturability $[10,14,15]$ & & $\mathrm{P}_{\mathrm{A} 9}$ : The use of flexible production technology $[16,27]$ \\
\hline & PL10: Innovation in performance assessment $[21,28]$ & & PA10: Willingness to improve knowledge and skill $[16,29]$ \\
\hline \multirow{10}{*}{ 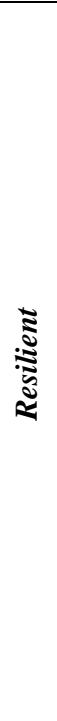 } & $\begin{array}{c}P_{R 1} \text { : Comprehend and implement risk management of supply } \\
\text { chain }[30,31]\end{array}$ & \multirow{10}{*}{$\frac{5}{5}$} & $\mathrm{P}_{\mathrm{G} 1}$ : Certification of ISO 14000 and OHSAS [32] \\
\hline & $P_{R 2}$ : Create viability along the supply chain [33-35] & & $\begin{array}{c}\text { PG2: Collaboration with supplier and consumer in maintaining } \\
\text { environmental sustainability [36] }\end{array}$ \\
\hline & $\begin{array}{l}\mathrm{P}_{\mathrm{R} 3} \text { : Implement the strategy of raw material sourcing } \\
\text { strategy for possible changes in supplier }[35,37,38]\end{array}$ & & $\begin{array}{c}\mathrm{P}_{\mathrm{G} 3} \text { : Environmentally-friendly design, innovation, operation, and } \\
\text { package }[39,40]\end{array}$ \\
\hline & $\begin{array}{c}\text { PR4: Develop cooperation in all production activities to } \\
\text { reduce risk [41-43] }\end{array}$ & & PG4: Waste sorting $[36,44,45]$ \\
\hline & 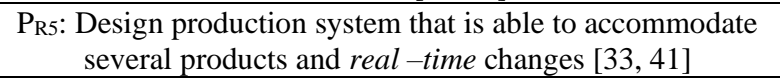 & & PG5: Increase environmental performance $[32,44]$ \\
\hline & $\mathrm{P}_{\mathrm{R} 6:}$ The use of flexible resources [35] & & $\mathrm{P}_{\mathrm{G} 6}:$ Conduct industrial waste recycling process $[32,36,46]$ \\
\hline & $\begin{array}{l}P_{\mathrm{R} 7} \text { : Implement disposition strategy to increase capacity } \\
\text { and/or stock concerning the "pinch point" potential [37] }\end{array}$ & & PG7: Perform CSR $[32,36]$ \\
\hline & $P_{R 8}:$ Implement demand based management $[41,43]$ & & $\begin{array}{l}\text { PG8: Design product that is able to reduce the consumption of } \\
\text { energy and raw material }[40,44,45]\end{array}$ \\
\hline & $\begin{array}{l}\mathrm{P}_{\mathrm{R} 9} \text { : Develop viability to clearly observe the condition of } \\
\text { production schedule and purchasing [47] }\end{array}$ & & $\begin{array}{l}\text { P }_{\mathrm{G} 9} \text { : Company is a part of green network that would share } \\
\text { information good practices concerning the environment }[6,44]\end{array}$ \\
\hline & $\begin{array}{c}\text { PR10: Develop viability to clearly control product related to } \\
\text { demand }[43,47]\end{array}$ & & PG10: The use of environmentally-friendly resources [45] \\
\hline
\end{tabular}

Table 2. The LARG index based on experts

\begin{tabular}{|c|c|c|c|}
\hline Behavior & $\begin{array}{c}\text { Average importance value based } \\
\text { on Experts } \\
\left(M_{x}\right)\end{array}$ & $\begin{array}{c}\text { Total of average importance } \\
\text { value } \\
\left(\sum_{g=1}^{n} M_{g}\right)\end{array}$ & $\begin{array}{c}\text { Weight of each } \\
\text { indicator } \\
\left(w_{x}\right)\end{array}$ \\
\hline Lean $\left(\mathrm{B}_{\mathrm{L}}\right)_{\mathrm{j}}$ & 4.49 & \multirow{4}{*}{18.12} & 0.248 \\
\hline Agile $\left(\mathrm{B}_{\mathrm{A}}\right)_{\mathrm{j}}$ & 4.79 & & 0.264 \\
\hline Resilient $\left(\mathrm{B}_{\mathrm{R}}\right)_{\mathrm{j}}$ & 4.21 & & 0.232 \\
\hline Green $\left(\mathrm{B}_{\mathrm{G}}\right)_{\mathrm{j}}$ & 4.63 & & 0.256 \\
\hline \multicolumn{3}{|c|}{ LARG Index $=0.248\left(B_{L}\right)_{j}+0.264\left(B_{A}\right)_{j}+0.232\left(B_{R}\right) j+0.256\left(B_{G}\right)_{j}$} & 4.540 \\
\hline
\end{tabular}

Table 2 shows the value for each lean, agile, resilient, and green behavior. According to Experts, agile (4.79) was the most important behavior compared to the other three behavior.

\subsection{Implementation of LARG issue of automotive industry in Indonesia}

Implementation of LARG issue in automotive industry was done in 10 automotive industries in Cikarang Indonesia consisted of 2 large car manufacturing industries, 2 large motorcycle manufacturing industries, 2 large component industries, 2 moderate component industries, and 2 small component industries. Assessment done by the director of each industry by self-assessment is presented in Table 3 .

The Result showed total average for lean (45.80), agile (44.30), resilient (44.40) and green (44.80) practices. Since the ideal average value for each practice is 50, all industries observed in this study have already implemented the LARG practice completely. Moreover, average value of LARG indicator implementation in automotive industry is shown in Table 4. Based on the average values of this industrial performance, the LARG index implemented in SMEs was possible to be determined by previously calculating the weight of each indicator $w_{L}, w_{A}, w_{R}, w_{G}$ using Delphi Eq. (3).

Moreover, the weight for each indicator of lean, agile, resilient, and green was calculated using the same procedure. Result of weight for each LARG indicator is listed in Table 4.

Based on Table 4, agile approach obtained the highest the highest score of implementation of 4.67 for all industry examined. Furthermore, LARG index for the ten industries reached 4.545 , indicating the industry observed in this study has already had partially implemented LARG approach. 
Table 3. Assessment result of LARG implementation in automotive industry

\begin{tabular}{|c|c|c|c|c|c|c|c|c|c|c|c|c|c|c|}
\hline \multirow{2}{*}{ Behavior } & \multirow{2}{*}{ Indicators } & \multicolumn{10}{|c|}{ Level of LARG Implementation } & \multirow{2}{*}{ Average } & \multirow{2}{*}{ Weight } & \multirow{2}{*}{ Rank } \\
\hline & & 1 & 2 & 3 & 4 & 5 & 6 & 7 & 8 & 9 & 10 & & & \\
\hline \multirow{11}{*}{ క్ } & $\mathrm{P}_{\mathrm{L} 1}$ & 5 & 5 & 5 & 5 & 3 & 4 & 5 & 5 & 4 & 5 & 4.600 & 0.100 & 4 \\
\hline & $\mathrm{P}_{\mathrm{L} 2}$ & 5 & 5 & 5 & 5 & 4 & 3 & 4 & 5 & 4 & 5 & 4.500 & 0.098 & 5 \\
\hline & $\mathrm{P}_{\mathrm{L} 3}$ & 5 & 5 & 5 & 5 & 3 & 4 & 5 & 5 & 5 & 5 & 4.700 & 0.103 & 3 \\
\hline & $\mathrm{P}_{\mathrm{L} 4}$ & 5 & 5 & 5 & 5 & 3 & 4 & 5 & 5 & 3 & 5 & 4.500 & 0.098 & 5 \\
\hline & $\mathrm{P}_{\mathrm{L} 5}$ & 5 & 5 & 5 & 5 & 5 & 5 & 5 & 5 & 5 & 5 & 5.000 & 0.109 & 1 \\
\hline & PL6 & 5 & 5 & 5 & 5 & 4 & 5 & 5 & 5 & 5 & 5 & 4.900 & 0.107 & 2 \\
\hline & $\mathrm{P}_{\mathrm{L} 7}$ & 5 & 5 & 5 & 5 & 4 & 3 & 4 & 5 & 4 & 3 & 4.300 & 0.094 & 6 \\
\hline & $\mathrm{P}_{\mathrm{L} 8}$ & 5 & 5 & 5 & 5 & 5 & 4 & 4 & 5 & 4 & 4 & 4.600 & 0.100 & 4 \\
\hline & PL9 & 5 & 5 & 5 & 5 & 5 & 3 & 5 & 5 & 4 & 5 & 4.700 & 0.103 & 3 \\
\hline & $P_{L 10}$ & 5 & 5 & 5 & 5 & 3 & 3 & 3 & 4 & 3 & 4 & 4.000 & 0.087 & 7 \\
\hline & & \multicolumn{10}{|c|}{ Total } & \multicolumn{3}{|c|}{45.800} \\
\hline \multirow{11}{*}{$\frac{\vec{\sigma}}{\vec{\sigma} 0}$} & $\mathrm{P}_{\mathrm{A} 1}$ & 5 & 5 & 5 & 5 & 5 & 5 & 4 & 4 & 5 & 4 & 4.700 & 0.106 & 1 \\
\hline & $\mathrm{P}_{\mathrm{A} 2}$ & 4 & 5 & 5 & 4 & 5 & 5 & 5 & 4 & 4 & 4 & 4.500 & 0.102 & 3 \\
\hline & $\mathrm{P}_{\mathrm{A} 3}$ & 5 & 5 & 5 & 4 & 4 & 5 & 4 & 5 & 4 & 5 & 4.600 & 0.104 & 2 \\
\hline & $\mathrm{P}_{\mathrm{A} 4}$ & 5 & 5 & 5 & 4 & 5 & 5 & 5 & 5 & 4 & 4 & 4.700 & 0.106 & 1 \\
\hline & $\mathrm{P}_{\mathrm{A} 5}$ & 4 & 5 & 4 & 5 & 5 & 5 & 4 & 4 & 4 & 5 & 4.500 & 0.102 & 3 \\
\hline & $\mathrm{P}_{\mathrm{A} 6}$ & 5 & 5 & 4 & 4 & 4 & 4 & 4 & 5 & 4 & 4 & 4.300 & 0.097 & 5 \\
\hline & $\mathrm{P}_{\mathrm{A} 7}$ & 5 & 5 & 5 & 5 & 5 & 5 & 5 & 4 & 3 & 3 & 4.500 & 0.102 & 3 \\
\hline & $\mathrm{P}_{\mathrm{A} 8}$ & 5 & 5 & 4 & 4 & 4 & 4 & 4 & 3 & 3 & 3 & 3.900 & 0.088 & 7 \\
\hline & $\mathrm{P}_{\mathrm{A} 9}$ & 4 & 5 & 5 & 4 & 5 & 5 & 4 & 4 & 3 & 3 & 4.200 & 0.095 & 6 \\
\hline & $\mathrm{P}_{\mathrm{A} 10}$ & 5 & 5 & 4 & 5 & 5 & 5 & 4 & 4 & 4 & 3 & 4.400 & 0.099 & 4 \\
\hline & & \multicolumn{10}{|c|}{ Total } & \multicolumn{3}{|c|}{44.300} \\
\hline \multirow{11}{*}{ 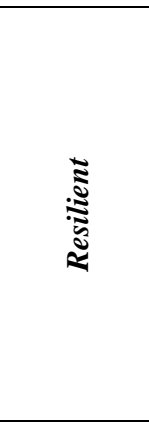 } & $P_{R 1}$ & 5 & 5 & 5 & 5 & 4 & 5 & 4 & 4 & 4 & 4 & 4.500 & 0.101 & 2 \\
\hline & $\mathrm{P}_{\mathrm{R} 2}$ & 5 & 5 & 4 & 5 & 4 & 5 & 5 & 4 & 4 & 4 & 4.500 & 0.101 & 2 \\
\hline & $\mathrm{P}_{\mathrm{R} 3}$ & 5 & 5 & 5 & 4 & 5 & 5 & 4 & 4 & 4 & 4 & 4.500 & 0.101 & 2 \\
\hline & $\mathrm{P}_{\mathrm{R} 4}$ & 5 & 5 & 5 & 4 & 5 & 4 & 4 & 4 & 4 & 5 & 4.500 & 0.101 & 2 \\
\hline & $\mathrm{P}_{\mathrm{R} 5}$ & 5 & 5 & 5 & 4 & 5 & 4 & 4 & 4 & 5 & 4 & 4.500 & 0.101 & 2 \\
\hline & $P_{R 6}$ & 5 & 5 & 4 & 4 & 5 & 4 & 4 & 5 & 4 & 5 & 4.500 & 0,101 & 2 \\
\hline & $\mathrm{P}_{\mathrm{R} 7}$ & 5 & 5 & 4 & 5 & 5 & 4 & 4 & 4 & 4 & 4 & 4,400 & 0.099 & 3 \\
\hline & $\mathrm{P}_{\mathrm{R} 8}$ & 5 & 5 & 5 & 5 & 5 & 5 & 4 & 4 & 4 & 4 & 4.600 & 0.104 & 1 \\
\hline & $\mathrm{P}_{\mathrm{R} 9}$ & 5 & 5 & 4 & 4 & 4 & 4 & 4 & 4 & 4 & 4 & 4.200 & 0.095 & 4 \\
\hline & $P_{\mathrm{R} 10}$ & 5 & 5 & 4 & 4 & 4 & 4 & 4 & 4 & 4 & 4 & 4.200 & 0.095 & 4 \\
\hline & & \multicolumn{10}{|c|}{ Total } & \multicolumn{3}{|c|}{44.400} \\
\hline \multirow{11}{*}{ కేँ } & $\mathrm{P}_{\mathrm{G} 1}$ & 5 & 5 & 5 & 5 & 5 & 5 & 4 & 4 & 3 & 3 & 4.400 & 0.098 & 5 \\
\hline & $\mathrm{P}_{\mathrm{G} 2}$ & 5 & 5 & 5 & 4 & 5 & 5 & 4 & 4 & 4 & 3 & 4.400 & 0.098 & 5 \\
\hline & $\mathrm{P}_{\mathrm{G} 3}$ & 5 & 5 & 5 & 4 & 5 & 5 & 5 & 5 & 5 & 5 & 4.900 & 0.109 & 1 \\
\hline & $\mathrm{P}_{\mathrm{G} 4}$ & 5 & 5 & 5 & 4 & 4 & 4 & 4 & 4 & 4 & 3 & 4.200 & 0.094 & 6 \\
\hline & $\mathrm{P}_{\mathrm{G} 5}$ & 5 & 5 & 5 & 4 & 5 & 5 & 5 & 4 & 4 & 3 & 4.500 & 0.100 & 4 \\
\hline & $\mathrm{P}_{\mathrm{G} 6}$ & 5 & 5 & 5 & 4 & 5 & 5 & 4 & 3 & 3 & 3 & 4.200 & 0.094 & 6 \\
\hline & $\mathrm{P}_{\mathrm{G} 7}$ & 5 & 5 & 5 & 5 & 5 & 5 & 5 & 5 & 3 & 3 & 4.600 & 0.103 & 3 \\
\hline & $\mathrm{P}_{\mathrm{G} 8}$ & 5 & 5 & 5 & 5 & 5 & 5 & 4 & 4 & 3 & 3 & 4.400 & 0.098 & 5 \\
\hline & $\mathrm{P}_{\mathrm{G} 9}$ & 5 & 5 & 5 & 5 & 5 & 5 & 4 & 4 & 4 & 3 & 4.500 & 0.100 & 4 \\
\hline & $\mathrm{P}_{\mathrm{G} 10}$ & 5 & 5 & 5 & 4 & 5 & 5 & 5 & 5 & 4 & 4 & 4.700 & 0.105 & 2 \\
\hline & & \multicolumn{10}{|c|}{ Total } & \multicolumn{3}{|c|}{44.800} \\
\hline
\end{tabular}

Note: Level 1-5 starts from 1 (do not implement LARG) to 5 (completely implement LARG).

Table 4. Implementation of LARG in automotive industry

\begin{tabular}{|c|c|c|c|}
\hline Behavior & $\begin{array}{c}\text { Average importance value based on } \\
\text { Experts } \\
\left(M_{x}\right)\end{array}$ & $\begin{array}{l}\text { Total of average importance value } \\
\qquad\left(\sum_{g=1}^{n} M_{g}\right)\end{array}$ & $\begin{array}{l}\text { Weight of each indicator } \\
\qquad\left(w_{x}\right)\end{array}$ \\
\hline Lean $\left(\mathrm{B}_{\mathrm{L}}\right)_{\mathrm{j}}$ & 4.60 & \multirow{4}{*}{18.17} & 0.253 \\
\hline Agile $\left(\mathrm{B}_{\mathrm{A}}\right)_{\mathrm{j}}$ & 4.67 & & 0.257 \\
\hline Resilient $\left(B_{R}\right)_{j}$ & 4.49 & & 0.247 \\
\hline Green $\left(\mathrm{B}_{\mathrm{G}}\right)_{\mathrm{j}}$ & 4.41 & & 0.243 \\
\hline \multicolumn{3}{|c|}{ LARG Index $=0.253\left(\mathrm{~B}_{\mathrm{L}}\right)_{\mathrm{j}}+0.257\left(\mathrm{~B}_{\mathrm{A}}\right)_{\mathrm{j}}+0.247\left(\mathrm{~B}_{\mathrm{R}}\right) \mathrm{j}+0.243\left(\mathrm{~B}_{\mathrm{G}}\right)_{\mathrm{j}}$} & 4.545 \\
\hline
\end{tabular}

When comparing LARG Index importance (Table 2) dan LARG Index implementation (Table 4) it can be seen that the LARG Index implementation is higher than importance. This means Indonesia automotive industry has actually implemented LARG approach. However, to see which approaches have been implemented properly can be seen in
Table 5 .

The next step was comparing implementation result of LARG practices in ten industries investigated to the importance value of LARG practices from Experts as presented in Table 5. The implementation value of lean and resilient is higher than the assessment of importance. This 
proves that the Indonesia automotive industry has good developed and implemented lean and resilient approach. However, implementation value of agile and green was slightly lower than the assessment of importance of LARG practices. For example, implementation value for agile in the industry was 4.67, lower than the value of importance from Experts of 4.79. According to Experts, this result showed that implementation level in the industry was slightly lower than it should be in order to have good competitiveness.

Table 5. Comparison of importance and implementation of LARG issue

\begin{tabular}{ccc}
\hline Indicators & Importance & Performance \\
\hline Lean behavior & 4.49 & 4.60 \\
Agile behavior & 4.79 & 4.67 \\
Resilient behavior & 4.21 & 4.49 \\
Green behavior & 4.63 & 4.41 \\
\hline LARG Index & $\mathbf{4 . 5 4 0}$ & $\mathbf{4 . 5 4 5}$ \\
\hline
\end{tabular}

\subsection{Sub indicators of LARG required to be improved}

The Importance Performance Analysis (IPA) was applied on each LARG indicator to determine which sub-indicators in each indicator required to be improved. Result of analysis is shown in Figures 2-5. In lean indicator, the sub-indicator to be improved was $\mathrm{P}_{\mathrm{L} 2}$ (reduce lot size) located in Quadrant II. This sub-indicator was found to have high importance according to Experts, but not yet completely implemented by industry. There was no sub-indicator from agile indicator in quadrant II, indicating that agile was almost completely implemented by industry. Sub-indicator in resilient that should be improved was $P_{R 10}$ (Develop visibility to clearly monitor the stock of goods and demand). Sub-indicator in green necessarily improved for its performance included $\mathrm{P}_{\mathrm{G} 1}$ (collaboration with supplier and consumer to maintain environment), $\mathrm{P}_{\mathrm{G} 3}$ (the use of natural resource), $\mathrm{P}_{\mathrm{G} 4}$ (environmentally-friendly design, innovation, operation, and package), $\mathrm{P}_{\mathrm{G} 5}$ (environmentallyfriendly label), and $\mathrm{P}_{\mathrm{G} 10}$ (reduce the level of stock). The green indicator was found to have the most sub-indicators to be improved which become the major concern for improving sustainable competitiveness. The green concept is also already applied in green supply chain management for agricultural products including several aspects such as green production, green transportation, green processing, and circulation, green consumption, and green recycle $[40,44]$.

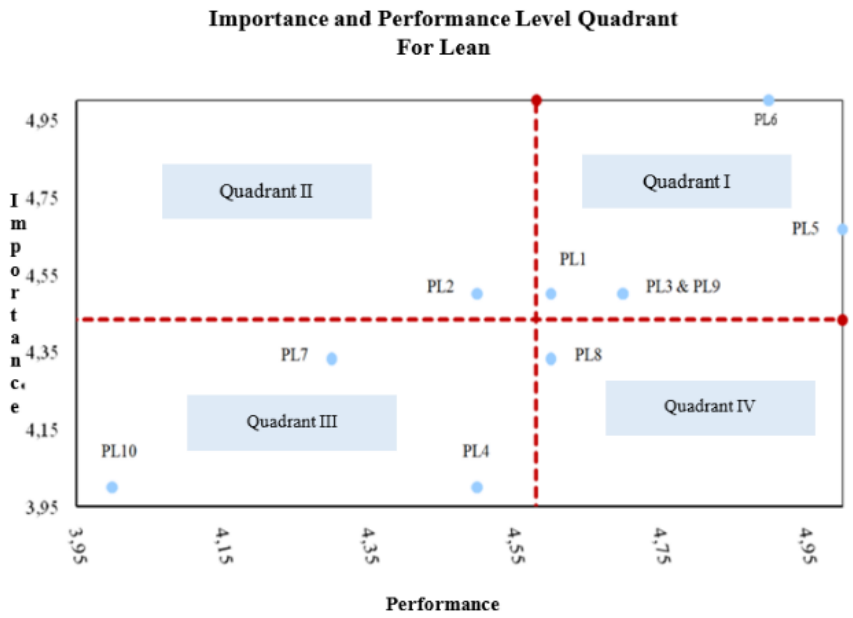

Figure 2. Mapping of importance and performance of lean sub-indicators
Importance and Performance Level Quadrant For Agile

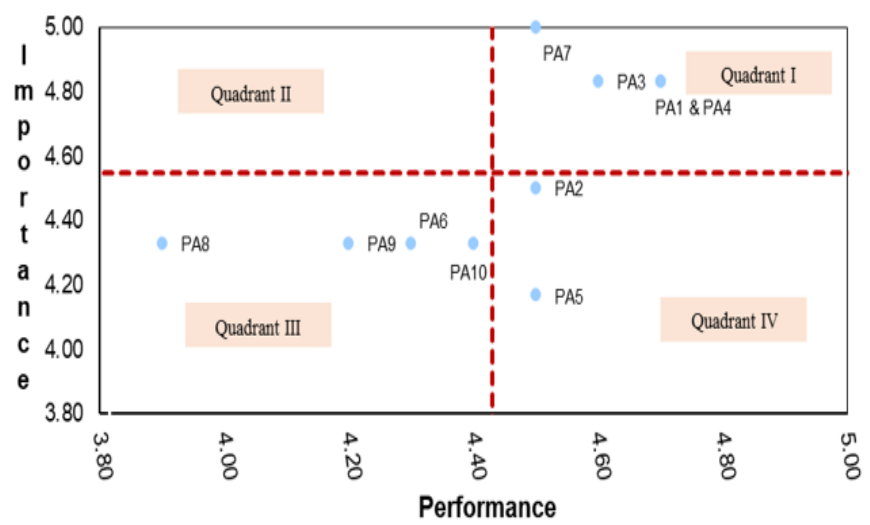

Figure 3. Mapping of importance and performance of agile sub-indicators

Importance and Performance Level Quandrant For Resilient

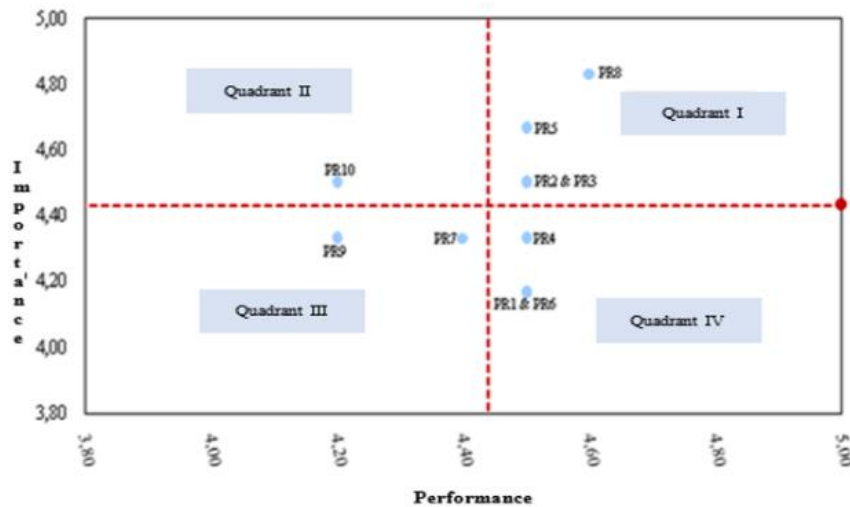

Figure 4. Mapping of importance and performance of Resilient sub-indicators

Importance and Performance Level Quandrant For Green

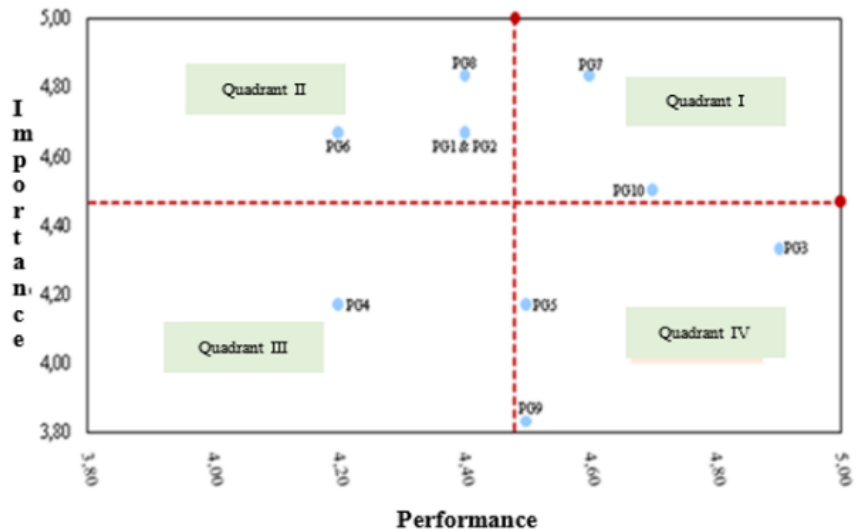

Figure 5. Mapping of importance and performance of green sub-indicators

This $\overline{\bar{X}}$ value is set perpendicular to the horizontal axis, that is, the axis that reflects the attribute performance $(\mathrm{X})$, while $\overline{\bar{Y}}$ the value crosses the vertical axis, which is the axis that reflects the attribute's importance (Y). After obtaining the weight of the performance and importance of the attributes, 
then these values are plotted into a Cartesian diagram. The average value of the score for the level of importance and performance is used to determine the points in the quadrant. The next interpretation is a combination of scores for the level of importance and quality of each attribute. The results of the analysis include different suggestions based on measures of importance (importance) and quality / spatial conditions (performance), which can then be used as a basis for recommendations.

\section{CONCLUSION}

Analysis result of the implementation of LARG approach in Indonesia automotive industry showed that several subindicators of LARG were not completely implemented. The green indicator was found to have the most sub-indicators that required improvement, namely $\mathrm{P}_{\mathrm{G} 1}$ (Certification of ISO 14000 and OHSAS), $\mathrm{P}_{\mathrm{G} 2}$ (Collaboration with supplier and consumer to maintain environmental sustainability), $\mathrm{P}_{\mathrm{G} 6}$ (Perform industrial waste recycling process) and $\mathrm{P}_{\mathrm{G} 8}$ (Design product to reduce energy and raw material consumption). However, according to the comparison of LARG index based on Experts and condition in the industry, implementation of LARG index was slightly higher with a value of 4.545 while importance reached 4.540 according to Experts. To sum, industry should improve the performance based on LARG approach, particularly concerning the green in order to increase sustainable competitiveness.

\section{ACKNOWLEDGMENT}

This article was created with financial support from MercuBuana University, Jakarta, Indonesia, to motivate the student and lecturer to have an innovative research thinking base.

\section{REFERENCES}

[1] Purba, H.H., Mukhlisin, Aisyah, S. (2018). Productivity improvement picking order by appropriate method, value stream mapping analysis, and storage design: A case study in automotive part center. Management and Production Engineering Review, 9(1): 71-81. https://doi.org/10.24425/119402

[2] Darmawan, H., Hasibuan, S., Purba, H.H. (2018). Application of Kaizen concept with 8 steps PDCA to reduce in line defect at pasting process: A case study in automotive battery. Int. J. Adv. Sci. Res. Eng., 4(8): $97-$ 107. https://doi.org/10.31695/ijasre.2018.32800

[3] Ikatrinasari, Z.F., Haryanto, E.I. (2014). Implementation of lean service with value stream mapping at directorate airworthiness and aircraft operation, ministry of transportation, republic of Indonesia. J. Service Science and Management, 7(4): 291-301. https://dx.doi.org/10.4236/jssm.2014.74026

[4] Cabral, I. (2012). An information model for lean, agile, resilient and green supply chain management. Fauldade Ciencias E Technol. Univ. Nona Lisboa, pp. 37-41.

[5] Aisyah, S., Jaqin, C., Purba, H.H. (2019). Identification of lean, agile, resilient, and green (larg) practices on agro industry Indonesia. 2019 1st International Conference on
Engineering and Management in Industrial System (ICOEMIS), 171: 62-69. https://doi.org/10.2991/icoemis-19.2019.10

[6] Aisyah, S., Machfud, Sukardi., Suparno, O. (2018). Assessment indeks lean and green Pada SMEs Cokelat bean to bar DI Indonesia. J. Teknol. Ind. Pertan, 28(3): 300-308.

https://doi.org/10.24961/j.tek.ind.pert.2018.28.3.301

[7] Grisham, T. (2009). The Delphi technique: A method for testing complex and multifaceted topics. Int. J. Manag. Proj. $\quad$ Bus., $2(1)$ : $112-130$. https://doi.org/10.1108/17538370910930545

[8] Azzopardi, E., Nash, R. (2013). A critical evaluation of importance - performance analysis. Tourism Management, 35: 222-233. https://doi.org/10.1016/j.tourman.2012.07.007

[9] Martilla, J.A., James, J.C. (1977). Importance performance analysis. Int. J. of Marketing, 41(1): 77-79. https://doi.org/10.2307/1250495

[10] Sanders, A., Elangeswaran, C., Wulfsberg, J. (2016). Industry 4.0 implies lean manufacturing: Research activities in industry 4.0 function as enablers for lean manufacturing. J. Ind. Eng. Manag., 9(3): 811-833. https://dx.doi.org/10.3926/jiem.1940

[11] Mostafa, S., Dumrak, J., Soltan, H. (2013). A framework for lean manufacturing implementation. Production \& Manufacturing Research, 1(1): 44-64. https://doi.org/10.1080/21693277.2013.862159

[12] Vinodh, S., Ramesh, K., Arun, C.S. (2016). Application of interpretive structural modelling for analysing the factors influencing integrated lean sustainable system. Clean Technol. Environ. Policy, 18(2): 413-428. https://doi.org/10.1007/s10098-015-1025-7

[13] Singh, A.K., Vinodh, S. (2017). Modeling and performance evaluation of agility coupled with sustainability for business planning. Journal of Management Development, 36(1): 109-128. https://doi.org/10.1108/JMD-10-2014-0140

[14] Wahab, A.N.A., Mukhtar, M., Sulaiman, R. (2013). A conceptual model of lean manufacturing dimensions. Procedia Technology, 11: 1292-1298. https://doi.org/10.1016/j.protcy.2013.12.327

[15] Rahman, N.A.A., Sharif, S.M., Esa, M.M. (2013). Lean manufacturing case study with Kanban system implementation. Procedia Economics and Finance, 7: 174-180. https://doi.org/10.1016/s2212-5671(13)002323

[16] Sangari, M.S., Razmi, J. (2015). Business intelligence competence, agile capabilities, and agile performance in supply chain: An empirical study. Int. J. Logist. Manag., 26(2): 356-380. https://doi.org/10.1108/IJLM-01-20130012

[17] Bhamu, J., Sangwan, K.S. (2014). Lean manufacturing: Literature review and research issues. Int. J. Oper. Prod. Manag., 34(7): 876-940. https://doi.org/10.1108/IJOPM08-2012-0315

[18] Gligor, D.M., Esmark, C.L., Holcomb, M.C. (2015). Performance outcomes of supply chain agility: When should you be agile? J. Oper. Manag., 33-34(1): 71-82. https://doi.org/10.1016/j.jom.2014.10.008

[19] Matawale, C.R., Datta, S., Mahapatra, S.S. (2016). Supplier selection in agile supply chain: Application potential of FMLMCDM approach in comparison with Fuzzy-TOPSIS and Fuzzy-MOORA. Benchmarking: An 
International Journal, 23(7): 2027-2060. https://doi.org/10.1108/BIJ-07-2015-0067

[20] Yang, J. (2014). Supply chain agility: Securing performance for Chinese manufacturers. Int. J. Prod. Econ., 150: 104-113. https://doi.org/10.1016/j.ijpe.2013.12.018

[21] Pinto, M.J.A., Mendes, J.V. (2017). Operational practices of lean manufacturing: Potentiating environmental improvements. J. Ind. Eng. Manag., 10(4): 550-580. https://dx.doi.org/10.3926/jiem.2268

[22] Purvis, L., Gosling, J., Naim, M.M. (2014). The development of a lean, agile and leagile supply network taxonomy based on differing types of flexibility. Int. J. Prod. Econ., 151: 100-111. https://doi.org/10.1016/j.ijpe.2014.02.002

[23] Pan, F., Nagi, R. (2013). Multi-echelon supply chain network design in agile manufacturing. Omega (United Kingdom), 41(6): 969-983. https://doi.org/10.1016/j.omega.2012.12.004

[24] Pentlicki, J.H. (2014). Barriers and success strategies for sustainable lean manufacturing implementation: A qualitative case study. University of Phoenix. ProQuest Dissertations Publishing.

[25] Fullerton, R.R., Kennedy, F.A., Widener, S.K. (2014). Lean manufacturing and firm performance: The incremental contribution of lean management accounting practices. Journal of Operations Management., 32(7-8): 414-428. https://doi.org/10.1016/j.jom.2014.09.002

[26] Beikkhakhian, B., Javanmardi, M., Karbasian, M., Khayambashi, B. (2015). The application of ISM model in evaluating agile suppliers selection criteria and rangking suppliers using fuzzy TOPSIS-AHP methods. Int. J. Expert Systems with Applications, 42(15-16): 6224-6236. https://doi.org/10.1016/j.eswa.2015.02.035

[27] Devor, R., Graves, R., Mills, J.J. (1997). Agile manufacturing research: Accomplishments and opportunities. IIE Transactions, 29(10): 813-823. https://doi.org/10.1080/07408179708966404

[28] Piercy, N., Rich, N. (2015). The relationship between lean operations and sustainable operations. Int. J. Oper. $\begin{array}{lll}\text { Prod. } & \text { Manag., } & \text { 35(2): }\end{array}$ https://doi.org/10.1108/IJOPM-03-2014-0143

[29] Baramichai, M., Zimmers, E.W., Marangos, C.A. (2007). Agile supply chain transformation matrix: An integrated tool for creating an agile enterprise. Supply Chain Manag., $\quad$ 12(5): 334-348. https://doi.org/10.1108/13598540710776917

[30] Pramanik, D., Haldar, A., Mondal, S.C., Naskar, S.K., Ray, A. (2017). Resilient supplier selection using AHPTOPSIS-QFD under a fuzzy environment. Int. J. Manag. Sci. Eng. Manag., 12(1): 45-54 https://doi.org/10.1080/17509653.2015.1101719

[31] Rajesh, R. (2018). Measuring the barriers to resilience in manufacturing supply chains using Grey Clustering and VIKOR approaches. Meas. J. Int. Meas. Confed., 126: 259-273. https://doi.org/10.1016/j.measurement.2018.05.043

[32] Zobel, T. (2016). The impact of ISO 14001 on corporate environmental performance: A study of Swedish manufacturing firms. J. Environ. Plan. Manag., 59(4): 587-606. https://doi.org/10.1080/09640568.2015.1031882

[33] Ali, A., Mahfouz, A., Arisha, A. (2017). Analysing supply chain resilience: Integrating the constructs in a concept mapping framework via a systematic literature review. Supply Chain Management, 22(1): 16-39. https://doi.org/10.1108/SCM-06-2016-0197

[34] Park, K. (2011). Flexible and redundant supply chain practices to build strategic supply chain resilience: contingent and resource-based perspectives. The University of Toledo, ProQuest Dissertations Publishing. 3507944.

[35] Sahu, A.K., Datta, S., Mahapatra, S.S. (2017). Evaluation of performance index in resilient supply chain: A fuzzybased approach. Benchmarking, 24(1): 118-142. https://doi.org/10.1108/BIJ-07-2015-0068

[36] Banaeian, N., Mobli, H., Fahimnia, B., Nielsen, I.E., Omid, M. (2016). Green supplier selection using fuzzy group decision making methods: A case study from the agri-food industry. Computer \& Operations Research, 89: 337-347. https://doi.org/10.1016/j.cor.2016.02.015

[37] Hosseini, S., Al Khaled, A. (2019). A hybrid ensemble and AHP approach for resilient supplier selection. J. Intell. $\quad$ Manuf., $30(1)$ : 207-228. https://doi.org/10.1007/s10845-016-1241-y

[38] Brandon-Jones, E., Squire, B., Autry, C.W., Petersen, K.J. (2014). A contingent resource-based perspective of supply chain resilience and robustness. J. Supply Chain Manag., $50(3)$ : 55-73. https://doi.org/10.1111/jscm.12050

[39] Subramanian, N., Gunasekaran, A. (2015). Cleaner supply-chain management practices for twenty-firstcentury organizational competitiveness: Practiceperformance framework and research propositions. Int. J. Prod. Econ., 164: 216-233. https://doi.org/10.1016/j.ijpe.2014.12.002

[40] Soda, S., Sachdeva, A., Garg, R.K. (2016). Implementation of green supply chain management in India: Bottlenecks and remedies. The Electricity Journal, 29(4): 43-50. https://doi.org/10.1016/j.tej.2016.05.003

[41] Gu, X., Jin, X.N., Ni, J., Koren, Y. (2015). Manufacturing system design for resilience. Procedia CIRP, 36: 135-140. https://doi.org/10.1016/j.procir.2015.02.075

[42] Lotfi, M., Sodhi, M., Kocabasoglu-Hillmer, C. (2013). How efforts to achieve resiliency fit with lean and agile practices. Proceedings of the 24th Production and Operations Management Society, Denver, USA, 3-6.

[43] Heinicke, M. (2014). Implementation of resilient production systems by production control. Procedia CIRP, 19: 105-110. https://doi.org/10.1016/j.procir.2014.05.001

[44] Ghazilla, R.A.R., Sakundarini, N., Abdul-Rashid, S.H., Ayub, N.S., Olugu, E.U., Musa, S.N. (2015). Drivers and barriers analysis for green manufacturing practices in Malaysian SMEs: A preliminary findings. Procedia CIRP, 26: 658-663. https://doi.org/10.1016/j.procir.2015.02.085

[45] Rostamzadeh, R., Govindan, K., Esmaeili, A., Sabaghi, M. (2015). Application of fuzzy VIKOR for evaluation of green supply chain management practices. Ecological Indicators, 49: 188-203. https://doi.org/10.1016/j.ecolind.2014.09.045

[46] Kusi-Sarpong, S., Bai, C., Sarkis, J., Wang, X. (2015). Green supply chain practices evaluation in the mining industry using a joint rough sets and fuzzy TOPSIS methodology. Resources Policy, 46(1): 86-100. https://doi.org/10.1016/j.resourpol.2014.10.011 
[47] Jabbour, C.J.C., Sousa Jabbour, A.B., Govindan, K., Freitas, T.P., Soubihia, D.F., Kannan, D., Latan, H. (2016). Barriers to the adoption of green operational practices at Brazilian companies: Effects on green and operational performance. Int. J. Prod. Res., 54(10): 30423058. https://doi.org/10.1080/00207543.2016.1154997 